\title{
KAJIAN EKOLOGI, KEANEKARAGAMAN JENIS DAN POTENSI POHON DI PEKARANGAN (STUDI KASUS DI DESA KEBAK, JUMANTONO, KARANGANYAR)
}

\author{
Arief Susanto $^{1)}$, Endang Setya Muliawati2) ${ }^{2}$ dan Djoko Purnomo ${ }^{2)}$ \\ ${ }^{1)}$ Mahasiswa Program Studi Agroteknologi Fakultas Pertanian UNS \\ ${ }^{2)}$ Program Studi Agroteknologi Fakultas Pertanian UNS \\ Email: djpuruns@gmail.com
}

\begin{abstract}
Homegarden is one alternative that multipurpose agricultural land to cope with reduced land resources. This study aimed to determine the characteristics of the ecology, species diversity and potential of trees in the homegarden that is useful in further development. The research had been conducted in June to August 2011 in the Kebak Village, Jumantono District, Karanganyar Regency with a altitude of 330 meters above sea level and soil type alvisol. This experiment used survey methods with observation unit is divided into three categories based on the size of the homegarden: narrow $\left(<700 \mathrm{~m}^{2}\right)$, medium $\left(700-900 \mathrm{~m}^{2}\right)$ and large $\left(>900 \mathrm{~m}^{2}\right)$. Observed variables include three aspects: biological variables (type and number of trees, tree height, trunk diameter and canopy area), physical variables (analysis of soil, microclimate homegarden, macroclimate and physiographic land) and analysis of the vegetation (density, frequency, dominance, relative density, relative frequency, relative dominance, importance value index and the index of species diversity). Kebak village had been 40 species of trees are divided into fruit trees, timber, vegetable producers, growers and others. The results showed indicate that the type of fruit tree had the largest of 20 species by the reached 142 tree to rambutan tree. Spacious homegarden area had the highest type and number of trees as well as the highest species diversity index.
\end{abstract}

Keywords: homegarden, trees and species diversity

\section{PENDAHULUAN}

Pertumbuhan penduduk di Indonesia mengalami peningkatan dari tahun ke tahun. Hal ini secara tidak langsung berdampak terhadap kebutuhan sumberdaya lahan, baik untuk pemukiman, pendidikan, tempat berusaha atau bercocok tanam. Penyusutan luas lahan sawah dan tegal sebagai lahan pertanian mengakibatkan penurunan kebutuhan pangan dan pendapatan para petani. Oleh sebab itu perlu upaya pemanfaatan lahan secara efesien untuk mengatasi masalah ini.

Pemanfaatan lahan pekarangan secara efektif dapat menjadi salah satu upaya memenuhi kebutuhan keluarga. Berdasarkan ekologinya pekarangan merupakan sistem yang terintegrasi kuat antara manusia, tanaman serta hewan. Oleh karena itu pekarangan merupakan salah satu model pemanfaatan lahan yang efektif dan berkelanjutan (Arifin et al. 2008). Pekarangan di kawasan pedesaan pada umumnya memiliki ukuran lahan reltif luas dengan jumlah keanekaragaman jenis tumbuhan yang cukup tinggi. Pada kebun atau pekarangan biasanya ditanami berbagai jenis tanaman yang produktif seperti pohon buah, sayuran dan tanaman obat. (Harun et al. 1999).

Penelitian pada skala pekarangan khususnya pada aspek ekologis sangat diperlukan untuk mengetahui karakteristik lahan, keanekaragaman jenis dan potensi tanaman (pohon) guna pengembangan lebih lanjut. Hasil penelitian ini diharapkan dapat memberi informasi bahwa pekarangan sebagai ekosistem dapat dijadikan unit usahatani sekaligus sebagai pendukung keanekaragaman hayati.

\section{METODE PENELITIAN}

Penelitian dilaksanakan pada bulan Juni Agustus 2011 yang bertepatan dengan musim kemarau. Tempat pelaksanaan penelitian berada di Desa Kebak, Kecamatan Jumantono, Kabupaten Karanganyar yang terletak antara $07^{\circ} 40^{\prime} 20,7^{\prime \prime}-07^{\circ} 40^{\prime} 56,2^{\prime \prime}$ LS dan $110^{\circ} 59^{\prime}$ $12,5^{\prime \prime}-111^{\circ} 00^{\prime} 45,3^{\prime \prime}$ BT dengan ketinggian 330 mdpl dan jenis tanah alvisol. Obyek yang digunakan adalah lahan pekarangan. Alat yang digunakan antara lain: GPS, Peta Desa Kebak, higrometer, termometer, kompas, klinometer, 
lux meter, alat tulis, kamera digital, roll meter dan tali.

Penelitian menggunakan metode survai dengan satuan amatan ditetapkan secara purposif yaitu berupa lahan pekarangan. Ukuran satuan amatan dibedakan berdasarkan luas lahan pekarangan (beserta rumah) menjadi 3 kategori yaitu luas lahan sempit $\left(<700 \mathrm{~m}^{2}\right)$, sedang $\left(700-900 \mathrm{~m}^{2}\right)$ dan luas $\left(>900 \mathrm{~m}^{2}\right)$. Pelaksanaan penelitian, meliputi: pendataan kepemilikan lahan, pengelompokan unit pekarangan dan penetapan sampel lahan pekarangan.

Variabel pengamatan meliputi 3 aspek, yaitu: variabel biologi (jenis pohon, jumlah pohon, tinggi pohon, diameter batang dan luas kanopi pohon), variabel fisik (analisis tanah, iklim mikro pekarangan, iklim makro dan fisiografi lahan) dan analisis vegetasi (kerapatan tumbuhan, frekuensi, dominansi, kerapatan relatif, frekuensi relatif, dominansi relatif, indeks nilai penting dan indeks keanekaragaman jenis)

\section{HASIL DAN PEMBAHASAN}

\section{Keadaan lingkungan}

Suhu, kelembaban, intensitas cahaya dan curah hujan

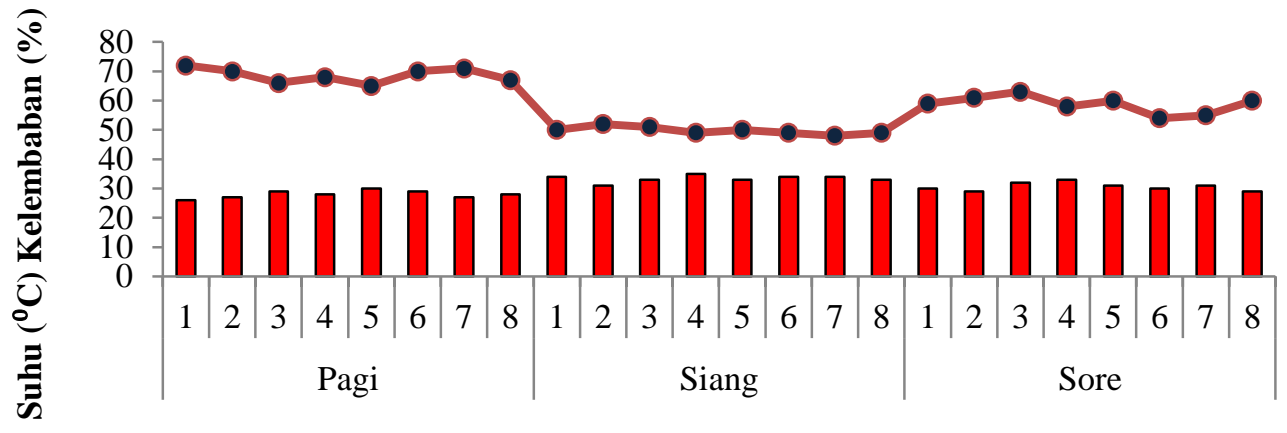

\section{Periode pengamatan \\ $\square$ Suhu $\rightarrow$ Kelembaban}

Gambar 1. Suhu dan kelembaban di pekarangan setiap 3 hari selama 1 bulan.

Suhu udara dalam pekarangan berkisar antara $26-30^{\circ} \mathrm{C}$ pada pagi hari, $31-35^{\circ} \mathrm{C}$ pada siang hari dan $29-33^{\circ} \mathrm{C}$ pada sore hari. Secara rata - rata suhu udara harian antara $26-35^{\circ} \mathrm{C}$ dan tidak berbeda tegas terutama pada siang dan sore hari. Kondisi ini menjadikan lahan pekarangan menciptakan iklim mikro yang berbeda dengan iklim setempat dengan suhu yang dapat mencapai $36-37{ }^{\circ} \mathrm{C}$ pada siang hari.

Kondisi suhu udara saling terkait dengan kelembaban udara. Suhu rendah pada pagi hari, semakin meningkat pada siang hari dan turun lagi pada sore hari berlawanan dengan kelembaban udara. Kelembaban udara pada pagi hari sebesar $65-72 \%$, semakin turun pada siang hari sebesar $48-52 \%$ dan meningkat kembali pada sore hari sebesar 54 -
$63 \%$. Seperti halnya suhu, kelembaban udara juga mengalami fluktuasi hal ini terjadi karena peningkatan suhu udara dan intensitas cahaya matahari.

Cahaya berperan dalam meningkatkan proses dan kerja enzim yang terlibat dalam proses fotosintesis (Jumin, 2002). Intensitas cahaya di pekarangan berkisar antara 586,7 13490,1 lux $\left(0,86-19,75 \mathrm{watt} / \mathrm{m}^{2}\right)$ dengan rata - rata intensitas di dalam kanopi sebesar 2214,44 lux $\left(3,24\right.$ watt $\left./ \mathrm{m}^{2}\right)$ dan 8308,22 lux $\left(12,16\right.$ watt $\left./ \mathrm{m}^{2}\right)$ di luar kanopi. Hasil pengamatan menunjukkan intensitas cahaya yang dapat lolos dari tajuk tanaman hanya sebesar $21 \%$ dari total intensitas cahaya keseluruhan. Sedikitnya cahaya yang lolos akan menguragi penguapan dan menjaga kelembaban di permukaan. 


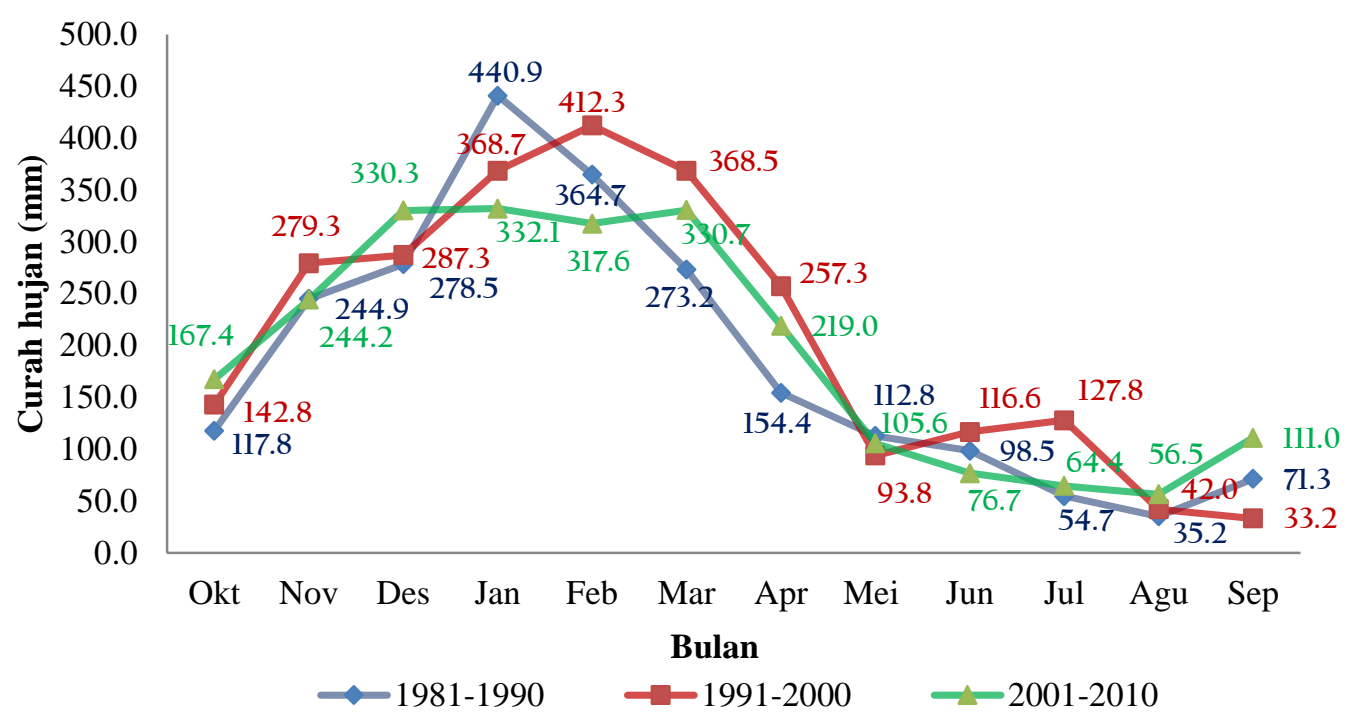

Gambar 2. Rerata intensitas curah hujan per 10 tahun.

Pada pengamatan curah hujan selama 30 tahun terakhir curah hujan tertinggi terjadi pada bulan Januari dengan rata - rata 380,5 $\mathrm{mm}$ per bulan sedangkan curah hujan terendah terjadi pada bulan Agustus dengan rata - rata $71,83 \mathrm{~mm}$ per bulan. Pada satu dekade terakhir curah hujan cenderung lebih rendah jika dibandingkan dengan dua dekade sebelumnya, jika hal ini akan terus berlanjut maka akan berpengaruh terhadap pasokan air untuk lahan pertanian. Berdasarkar perhitungan iklim menurut Schmidt-Ferguson hasil perhitungan nilai Q selama 30 tahun sebesar $48,65 \%$, $53,42 \%$ dan $57,06 \%$ yang termasuk dalam tipe iklim C (agak basah). Pada tahun 2011 menunjukkan intensitas hujan cukup tinggi terjadi pada bulan Maret dan April yaitu sebesar 456 dan $448 \mathrm{~mm}$ sedangkan pada intesitas hujan sangat rendah bahkan sampai mencapai angka 0 terjadi pada bulan Juni, Agustus dan September yang menandakan tidak ada hujan selama 1 bulan. Hasil pengamatan menunjukkan indikasi terjadinya penyimpangan iklim.

1. Ketinggian tempat dan kemiringan lahan

Desa Kebak memiliki rerata tinggi tempat sekitar 333,17 mdpl dengan kemiringan lahan sekitar 4,67\%. Hasil pengamatan tidak menunjukkan perbedaan yang signifikan dengan data monografi desa yaitu sekitar 330 mdpl. Hal ini dikarenakan letak sampel pekarangan yang berada di sekitar pusat desa sehingga data yang diperoleh relatif sama. Kemiringan lahan tidak begitu curam hal ini dikarenakan sampel pekarangan yang berada di sepanjang jalan utama desa cenderung lebih datar.

2. Karakteristik tanah

Jenis tanah pekarangan di lokasi penelitian adalah tanah alvisols dengan perbandingan tekstur tanah, yaitu: debu $(49,52 \%)$, liat $(28,1 \%)$ dan pasir $(22,38 \%)$. Berdasarkan hasil analisis menunjukkan bahwa tekstur debu yang lebih dominan dibandingkan tekstur yang lain. Tanah seperti ini disebut tanah berlempung yaitu tanah yang proporsi pasir, debu dan liat sedemikian rupa sehingga sifatnya berada diantara tanah berpasir dan berliat. Aerasi dan daya hantar air cukup baik sehingga mampu menyediakan dan menyimpan air untuk tanaman (Islami, 1995). Berdasarkan hasil analisis tanah bahwa keadaaan tanah di pekarangan desa Kebak mengandung N, $\mathrm{P}$ dan $\mathrm{K}$ yang rendah. Kandungan $\mathrm{BO}$ pekarangan tinggi dikarenakan banyaknya seresah yang jatuh berserakan pada lahan pekarangan. Keasaman tanah $(\mathrm{pH})$ yang netral serta kandungan C.organik yang sedang akan membuat mikroba tanah mampu beraktivitas dengan baik untuk membantu dalam proses pertumbuhan tanaman. 


\section{Sistem pertanian}

Umum

Tabel 1. Jumlah penduduk menurut mata pencaharian di desa Kebak

\begin{tabular}{clcc}
\multirow{2}{*}{ No } & \multicolumn{2}{c}{ Jenis mata pencaharian } & \multicolumn{2}{c}{ Jumlah penduduk } \\
\cline { 3 - 4 } & & Jumlah & Persen (\%) \\
\hline 1 & Karyawan & 35 & 0,92 \\
& a. Pegawai Negeri Sipil & 5 & 0,13 \\
& b. TNI/POLRI & 995 & 26,24 \\
& c. Swasta & 29 & 0,76 \\
2 & Wiraswasta/pedagang & $\mathbf{2 3 4 1}$ & $\mathbf{6 1 , 7 4}$ \\
$\mathbf{3}$ & Petani & 31 & 0,82 \\
5 & Pertukangan & 9 & 0,24 \\
6 & Pensiunan & 16 & 0,42 \\
7 & Angkutan & 13 & 0,34 \\
8 & Jasa & 318 & 8,39 \\
9 & Lainnya $\quad$ Keseluruhan & 3792 & 100 \\
& & &
\end{tabular}

Sumber : Data monografi desa Kebak.

Tabel 2. Luas wilayah desa Kebak

\begin{tabular}{lcc}
\hline \multirow{2}{*}{ Lahan } & \multicolumn{2}{c}{ Luas (ha) } \\
\cline { 2 - 3 } & Juni & November \\
\hline Sawah & 172,11 & 201,35 \\
- Irigasi teknis & 30,2 & 92,26 \\
- Irigasi setengah teknis & 58,4 & 79,19 \\
- Irigasi sederhana & 38,3 & 18 \\
- Tadah hujan & 46,19 & 10 \\
Tegal/Kebun & 395,32 & 345,35 \\
Pekarangan & $\mathbf{2 4 , 6 8}$ & $\mathbf{4 5 , 4 1}$ \\
\hline & & 592,11 \\
\hline
\end{tabular}

Sumber : Data monografi desa Kebak.

Jumlah petani di desa Kebak mencapai 2341 jiwa atau sekitar $61,74 \%$. Jumlah tersebut paling tinggi daripada jumlah mata pencaharian yang lain. Tingginya masyarakat bermatapencaharian sebagai petani didasari karena luasnya lahan pertanian di desa Kebak.

Pada tabel 2 dipaparkan bahwa terjadinya pergeseran fungsi lahan yang awalnya tegal menjadi lahan sawah dan pekarangan. Menurut Rustiadi et al. (2008) pergeseran fungsi lahan merupakan proses pemanfaatan sumberdaya menuju keseimbangan baru yang lebih optimal. Pergeseran fungsi lahan tegal menjadi lahan sawah bertujuan untuk mendapatkan hasil dan pendapatan yang lebih optimal daripada sebelumnya, sedangkan pergeseran menjadi lahan pekarangan didasari karena kebutuhan lahan untuk tempat tinggal.

Pekarangan merupakan kebun campuran dan salah satu contoh sistem agroforestri yang menggabungkan antara tanaman pertanian dan tanaman pepohonan multiguna untuk memenuhi kebutuhan masyarakat (Nair, 1993). Jenis tanaman yang di tanam beranekaragam yaitu: tanaman buah, sayuran, tanaman herba dan tanaman semusim. 


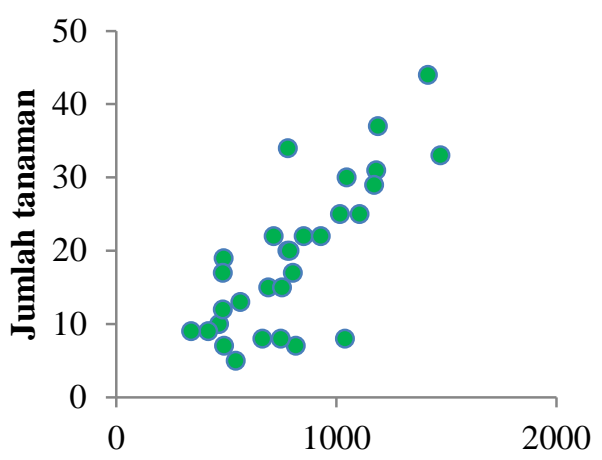

Luas pekarangan ( $\left.\mathbf{m}^{2}\right)$

Gambar 3. Sebaran jumlah pohon pada lahan pekarangan

Pada pengamatan sebaran pohon dapat dilihat bahwa jumlah pohon terbanyak terdapat pada luasan pekarangan $1413,7 \mathrm{~m}^{2}$ dengan 44 pohon. Pekarangan yang memiliki jumlah pohon paling sedikit terdapat pada luasan $541,39 \mathrm{~m}^{2}$ dengan 5 pohon. Berdasarkan hasil ini dapat diketahui bahwa semakin luas lahan yang dimiliki maka akan semakin banyak pohon yang ditanam.

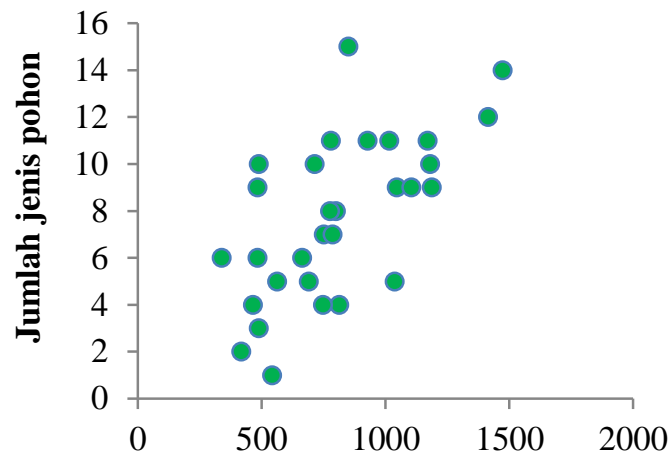

Luas pekarangan $\left(\mathrm{m}^{2}\right)$

Gambar 4. Sebaran jumlah jenis pada lahan pekarangan

Pada pengamatan sebaran jenis pohon di pekarangan dapat diketahui bahwa jumlah jenis pohon terbanyak terdapat pada luasan $1471,96 \mathrm{~m}^{2}$ dengan 14 jenis pohon. Pekarangan yang memiliki jenis pohon paling sedikit terdapat pada luasan $541,39 \mathrm{~m}^{2}$ dengan 1 jenis pohon. Berdasarkan hasil pengamatan dapat diketahui bahwa semakin luas lahan yang dimiliki maka akan semakin banyak variasi tanaman.

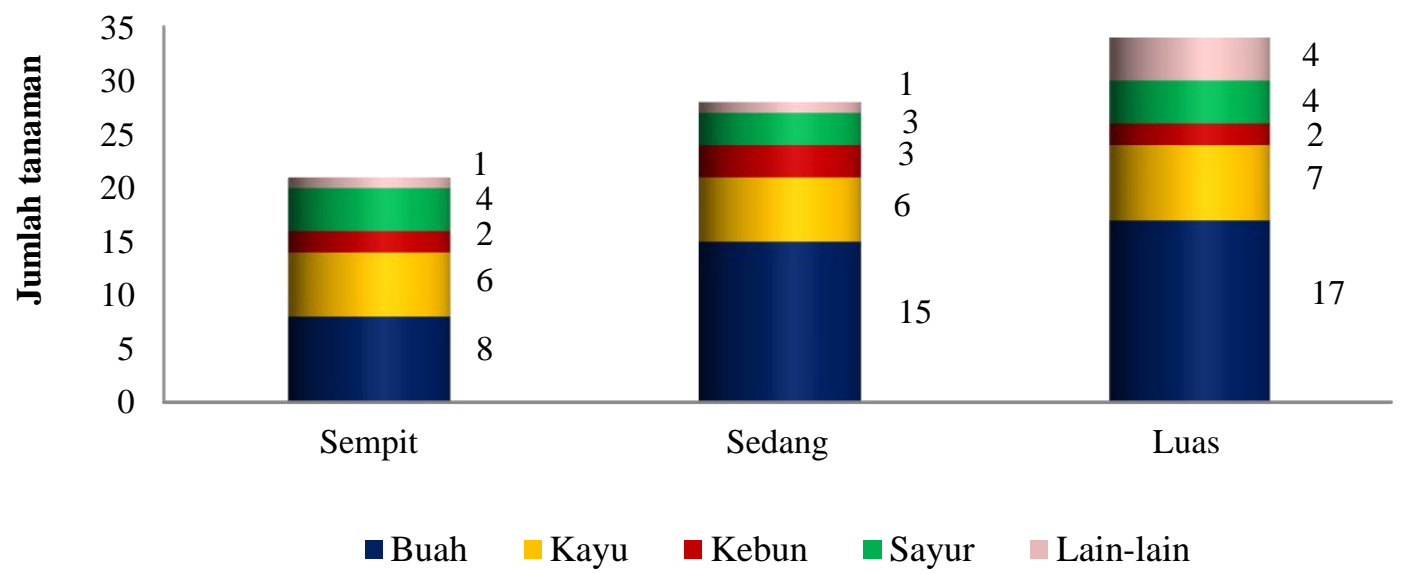

Gambar 5. Jumlah jenis pohon pada tiap luasan pekarangan.

Penanaman pohon di lahan pekarangan desa Kebak cukup bervariasi, hal ini dapat dilihat dari komposisi jenis pohon yang ada pada tiap luasan pekarangan. Pohon buah mendominasi pada tiap luasan yaitu 8 jenis pada pekarangan sempit, 15 jenis pada pekarangan sedang dan 17 jenis pada pekarangan luas. Jenis pohon kayu berada pada urutan kedua yang mendominasi pada tiap luasan yaitu: 6 jenis pada pekarangan sempit, 6 jenis pada pekarangan sedang dan 7 jenis pada pekarangan luas. 
Tabel 3. Nama jenis dan jumlah individu pohon di pekarangan

\begin{tabular}{clc}
\hline No & Jenis & Jumlah \\
\hline & Buah & \\
1 & Rambutan & 142 \\
2 & Mangga & 45 \\
3 & Nangka & 39 \\
4 & Durian & 37 \\
5 & Jambu mete & 8 \\
6 & Sawo & 7 \\
7 & Kelengkeng & 4 \\
8 & Pakel & 4 \\
9 & Alpukat & 3 \\
10 & Belimbing & 3 \\
11 & Jambu biji & 3 \\
12 & Jambu air & 2 \\
13 & Kedondong & 2 \\
14 & Sirsak & 2 \\
\hline
\end{tabular}

\begin{tabular}{clc}
\hline No & Jenis & Jumlah \\
\hline 15 & Srikaya & 2 \\
16 & Sukun & 2 \\
17 & Duku & 1 \\
18 & Jeruk & 1 \\
19 & Jeruk bali & 1 \\
20 & Jeruk nipis & 1 \\
& Perkebunan & \\
21 & Kelapa & 47 \\
22 & Coklat & 14 \\
23 & Cengkeh & 3 \\
& Penghasil sayur & \\
24 & Melinjo & 21 \\
25 & Petai & 19 \\
26 & Jengkol & 6 \\
27 & Lamtoro & 3 \\
\hline
\end{tabular}

\begin{tabular}{llc}
\hline No & Jenis & Jumlah \\
\hline & Kayu & \\
28 & Mahoni & 62 \\
29 & Jati & 45 \\
30 & Sengon & 22 \\
31 & Johar & 2 \\
32 & Senu & 2 \\
33 & Bendo & 1 \\
34 & Sono keling & 1 \\
35 & Waru & 1 \\
& Lain - lain & \\
36 & Randu & 5 \\
37 & Mengkudu & 3 \\
38 & Salam & 3 \\
39 & Beringin & 1 \\
40 & Palem & 1 \\
\hline
\end{tabular}

Hasil pengamatan menunjukkan bahwa tanaman pohon buah memiliki jumlah paling banyak dibandingkan dengan jenis pohon yang lain. Beberapa pohon buah yang paling banyak di tanam, antara lain: rambutan, mangga, nangka dan durian. Pohon jenis buah lebih digemari masyarakat karena dari segi ekonomi lebih menguntungkan serta dapat menghasilkan buah sepanjang musim sehingga dapat memberi tambahan pendapatan bagi petani.

\section{Analisis vegetasi}

Pada pengamatan analisis vegetasi, pohon rambutan sangat mendominasi pada tiap parameter, yaitu pada kerapatan sebesar 0,0089; 0,0062; 0,0046; pada dominansi sebesar 0,$2490 ; 0,167 ; 0,139$; pada frekuensi sebesar $1 ; 0,89 ; 1$; pada kerapatan relatif sebesar 39,99\%; 26,21\%; $18,80 \%$; pada dominansi relatif sebesar $33,34 \%$; 22,29\%; 22,25\%; pada frekuensi relatif sebesar $19,30 \%$; $10,81 \%$; 9,90\%; dan pada pengamatan INP sebesar $92,62 \%$; $59,31 \%$; 50,95\%. Pohon jenis rambutan mempunyai nilai paling tinggi diantara yang lain, hal ini menandakan bahwa pohon rambutan sangat disukai mayarakat. Rambutan disukai masyarakat karena perawatan mudah, tahan terhadap hama dan hasilnya dapat dinikmati secara kontinyu.

Kenakeragaman jenis yang tinggi menunjukkan bahwa suatu komunitas memiliki kompleksitas yang tinggi (Soegianto, 1994). Pada pengamatan indeks keanekaragaman jenis diperoleh hasil bahwa keanekaragaman jenisnya tertinggi yaitu mencapai 1,263 pada lahan pekarangan luas. Hal ini menandakan bahwa semakin luas pekarangan maka keanekaragaman jenisnya semakin tinggi.

2. Vegetasi pekarangan

a. Keanekaragaman jenis pohon Jenis pohon buah banyak ditemui di tiap pekarangan di desa kebak. Jenis tanaman buah yang paling banyak di tanam antara lain rambutan, mangga, durian dan nangka. Pohon rambutan memiliki jumlah terbanyak yaitu 142 pohon. Jenis tanaman buah lain yang mendominasi adalah mangga, durian, kelapa dan nangka. Kelima komoditas jumlahnya sangat banyak dikarenakan termasuk komositas yang diminati pasar dan mempunyai harga jual cukup tinggi. Jenis pohon kayu yang banyak ditemui di pekarangan adalah mahoni, jati dan sengon. Jumlah pohon mahoni paling banyak pada luasan $\left(>900 \mathrm{~m}^{2}\right)$ yaitu sebanyak 41 pohon. Secara keseluruhan jumlah pohon mahoni dan jati mendominasi jenis pohon kayu pada lahan pekarangan yaitu sebanyak 62 dan 44 pohon..

Jenis pohon perkebunan yang paling banyak di temui di pekarangan adalah kelapa. Jumlah pohon kelapa paling banyak ditemukan pada lahan pekarangan yang luas yaitu sebanyak 27 
pohon. jumlah pohon kelapa untuk pekarangan sempit dan sedang sebanyak 11 dan 9 pohon.

b. Diameter pohon

Berdasarkan klasifikasi pohon yang di kemukakan oleh Kadri et al. (1992) bahwa pekarangan didominasi oleh tanaman fase tiang (poles) yaitu dengan 274 pohon. Jumlah pohon pada fase lain, yaitu: fase pohon inti (nucleus tress) sebanyak 189 pohon, fase sapihan (saplings) sebanyak 103 pohon dan fase pohon besar (tress) sebanyak 7 pohon. Pohon dengan fase tiang di dominasi oleh tanaman buah seperti : rambutan, mangga, durian dan nangka.

c. Tinggi pohon

Pengamatan tinggi pohon ditujukan untuk mengetahui pelapisan tajuk antara tanaman tinggi, sedang dan rendah dalam pekarangan. Berdasarkan lima kelas stratum yang di kemukakan oleh Arief (1994) hasil dari pengamatan pohon pekarangan tergolong dalam stratum C dan D. Stratum C merupakan lapisan tajuk ketiga dari atas yang dibentuk oleh pohon dengan tinggi 4-20 $\mathrm{m}$ sedangkan stratum D merupakan lapisan tajuk ke empat dari atas yang dibentuk oleh tanaman atau pohon dengan tinggi 1-4 m. Berdasarkan pengamatan tanaman tergolong stratum C sebanyak 556 pohon $(97,03 \%)$. Tanaman yang tergolong stratum D sebanyak 17 pohon $(2,97 \%)$.

d. Luas kanopi pohon

Pekarang di desa Kebak didominasi oleh pohon dengan luas kanopi antara 0 - 19,9 $\mathrm{m}^{2}$ dan 20 - 39,9 $\mathrm{m}^{2}$. Pohon yang tergolong mempunyai kanopi luas antara lain: rambutan, kelapa dan durian. Penutupan lahan yang dilakukan oleh pohon tersebut sangat mempengaruhi jumlah intensitas cahaya yang masuk di lahan pekarangan. Penutupan lahan yang terjadi akan menimbulkan persaingan antara tanaman yang membutuhkan cahaya (intoleran) dan tanaman yang membutuhkan naungan (toleran) (Indriyanto, 2005).

3. Pengelolaan pekarangan

Pengolahan pekarangan dan budidaya tanaman pohon di desa Kebak masih belum optimal, hal ini dikarenakan tanaman hanya dibiarkan tumbuh liar dan tidak diberi nutrisi yang cukup. Tanaman hanya diberi air sebagai nutrisi tambahan untuk tumbuh tanpa ada olah tanah ataupun pemupukan untuk menunjang pertumbuahan tanaman. Oleh karena itu perlu upaya untuk mengatasi masalah tersebut salah satunya adalah dengan pola manajemen sumberdaya lahan. Menurut Lal (1995) dalam Rustiadi et al. (2008) manajemen sumberdaya lahan pada dasarnya adalah penerapan cara pemeliharaan lahan melalui upaya peningkatan kualitas tanah dan perbaikan karakteristik lingkungan pada lahan. Lahan yang berkualitas adalah lahan mampu mengahasilkan produk pertanian dan dapat mempertahankan dari kerusakan lingkungan.

Kualitas suatu lahan sangat tergantung dari sifat - sifat tanah yang terkandung di dalamnya. Sifat tanah yang penting antara lain: struktur tanah, bahan organik tanah, kandungan kimia tanah $(\mathrm{N}, \mathrm{P}, \mathrm{K})$ dan ketersediaan air (Lal, 1995) dalam (Rustiadi et al. 2008). Berdasarkan hasil analisis bahwa tanah pekarangan desa Kebak kandungan sifat tanahny rendah oleh sebab itu perlu adanya penambahan nutrisi baik pupuk atau miroorganisme tanah di pekarangan yang dapat membantu pertumbuhan tanaman secara optimal.

\section{KESIMPULAN DAN SARAN}

Kesimpulan yang dapat diambil dari hasil penelitian adalah Desa Kebak memiliki 40 jenis pohon yang dibagi atas pohon buah, kayu, penghasil sayur, perkebunan dan lain lain. Jenis pohon buah memiliki jumlah terbanyak yaitu 20 jenis dengan jumlah pohon rambutan mencapai 142 pohon. Lahan pekarangan luas memiliki jenis dan jumlah pohon terbanyak serta indeks keanekaragaman jenis tertinggi.

Saran yang dapat penulis berikan perlu adanya kajian lebih lanjut terutama mengenai kandungan air dan tanah untuk mendukung dalam pemanfaatan pekarangan di masa depan.

\section{DAFTAR PUSTAKA}

2008. Pengantar Budidaya Hutan. PT Bumi Aksara. Jakarta 234 hal.

Abdoellah, $\mathrm{O}$ et al. 2006. Commercialization of homegardens in an indonesian village: 
vegetation composition and functional changes. agroforestry systems 68:1-13. Japan

Arief, A. 1994. Hutan : Hakikat dan pengaruhnya terhadap lingkungan. Fakultas Kehutanan Institut Pertanian Bogor.

Arifin, HS. et al. 2008. Revitalisai pekarangan sebagai agroekosistem dalam mendukung ketahanan pangan di wilayah pedesaan. Prosiding Semiloka 22-23 Desember 2008.

Indriyanto, 2005. Ekologi Hutan. PT Bumi Aksara. Jakarta 210 hal.

Islami, T. 1995. Hubungan Tanah, Air dan Tanaman. Ikip Semarang Press

Jumin, H.B. 2002. Agroekologi: Suatu Pendekatan Fisiologis. PT RajaGrafindo Persada. Jakarta.

Kadri, W. dkk. 1992. Manual Kehutanan. Jakarta : Departemen Kehutanan Repuplik Indonesia.

Krisna, W. 1994. Kondisi hidrologi daerah Kecamatan Jumantono, Jumapolo dan sekitarnya Kabupaten Karanganyar Provinsi Jawa Tengah. Fakultas Teknik, Universitas Diponegoro Semarang.
Odum, E.P. 1993. Dasar-Dasar Ekologi. Gadjah Mada University Press. Yogyakarta.

Perrault, M and Coomes, T. 2008. Distribution of agrobiodiversity in home gardens along the corrientes river, peruvian Amazon. Economic Botany, pp. 109-126. The New York Botanical Garden Press.

Rahayu, M. dan S. Prawiroatmodjo. 2005. Keanekaragaman tanaman pekarangan dan pemanfaatannya di Desa Lampeapi, Pulau Wawoni - Sulawesi Tenggara. herbarium bogoriense. Bidang Botani Pusat Penelitian Biologi, LIPI. Jurnal Teknologi Lingkungan P3TL-BPPT. 6.(2): $360-364$

Rustiadi, E. et al. 2008. Penyelamatan Tanah, Air, dan Lingkungan. Crestpent Press Bogor dan Yayasan Obor Indonesia Jakarta

Soegianto, A. 1994. Ekologi Kuantitatif : Metode Analisis Populaasi dan Komunitas. Jakarta : Penerbit Usaha Nasional.

Soemarwoto, O. 1991. Ekologi, Lingkungan Hidup, dan Pembangunan. Penerbit Djambatan. Jakarta. 362 hal. 